\title{
HEAVY METAL CONCENTRATION IN EIGHT FISH SPECIES FROM EPE LAGOON (NIGERIA)
} Iyabode Olusola TAIWO *, Olaniyi Alaba OLOPADE ** and Nathanael Akinsafe BAMIDELE *

* Federal University of Agriculture IFSERAR, P. M. B., 2240, Abeokuta, Ogun State, Nigeria, NG-110212, Iomtai@yahoo.com, bamidelena@funnab.edu.ng

** University of Port-Harcourt, Choba, Department of Fisheries, P. M. B., 5323, Port-Harcourt, Rivers State, Nigeria, NG-500211, olaniyi.olopade@uniport.edu.ng

DOI: 10.2478/trser-2019-0006

KEYWORDS: fish muscle, heavy metals, maximum concentration, Epe Lagoon, Nigeria.

\section{ABSTRACT}

This research was undertaken to find out the levels of five heavy metals $(\mathrm{Cu}, \mathrm{Fe}, \mathrm{Mn}$, $\mathrm{Pb}$, and $\mathrm{Zn}$ ) in the muscles of eight fish species from Epe Lagoon. The levels of heavy metals were determined by atomic absorption spectrophotometry after digestion of the samples using Kjldahl heating digester. The heavy metal concentrations among the fish species were statistically dissimilar $(\mathrm{P}<0.5)$. The heavy metals of $\mathrm{Pb}, \mathrm{Fe}$, and $\mathrm{Mn}$ were above the FAO/WHO agreeable limits for human consumption.

ZUSAMMENFASSUNG: Schwermetallkonzentration in acht Fischarten der Epe Lagune (Nigeria).

Vorliegende Studie befasst sich mit den Ergebnissen einer Untersuchung, deren Ziel es war, die Höhe des Gehalts von fünf Schwermetallen $(\mathrm{Cu}, \mathrm{Fe}, \mathrm{Mn}, \mathrm{Pb}$ und $\mathrm{Zn})$ in acht Fischarten der Epe-Lagune zu bestimmen. Die Höhe des Schwermetallgehalts wurde mit Hilfe eines Atom Absorbtions-Spektrophotometers nach Digestion der Proben durch einen kjldahl geheizten Digester gemessen. Die Schwermetallkonzentration bei den Fischarten war statistisch unterschiedlich $(\mathrm{P}<0.5)$. Die $\mathrm{Pb}-$, Fe- und $\mathrm{Mn}$ - Konzentrationen lagen alle über den von der FAO/WHO akzeptierten Grenzwerten, die den Verzehr der Fische durch den Menschen erlauben. (Nigeria).

REZUMAT: Concentrații de metale grele în opt specii de pești din laguna Epe

Scopul prezentului studiu a fost determinarea gradului de contaminare cu cinci metale grele $(\mathrm{Cu}, \mathrm{Fe}, \mathrm{Mn}, \mathrm{Pb}$ şi $\mathrm{Zn})$ măsurat în muşchii a opt specii de pești din laguna Epe (Nigeria). Conținutul în metale grele a fost măsurat cu ajutorul unui spectrofotometru de absorbție atomică după digerarea probelor folosindu-se un aparat Kjldahl de digestie prin încălzire. Concentrația de metale grele la speciile de pești analizate a fost diferită din punct de vedere statistic $(\mathrm{P}<0.5) . \mathrm{Pb}, \mathrm{Fe}$, and $\mathrm{Mn}$ au depășit la toate probele luate din pești valorile limită acceptate de $\mathrm{FAO} / \mathrm{WHO}$ pentru consum alimentar. 


\section{INTRODUCTION}

Heavy metal pollution is an important issue in a lot of aquatic and semi-aquatic habitats and the products obtained globally from them, particularly where there are industries which dispatch their waste into or close to the water bodies (Astratinei and Varduca, 2008; Zubcov et al., 2008; Iepure and Selescu, 2009; Aziz and Hashim, 2011; Akköz, 2016). Heavy metal pollution in the lagoons and estuaries in Nigeria has not been properly documented, including the fishery resources of this country.

Fish and fish products are an important part of a healthy diet, especially in developing countries, where it is a source of cheap animal protein. Fish also contain other essential nutrients, and they are low in saturated fat and contain omega three fatty acids (NSPFS, 2005).

Heavy metals are natural trace elements of the marine habitats, but they are also one of the most dangerous substances that could be accumulated in biota. Munoz-Olivas and Camara (2001) observed that commercially important fish species often live in coastal environments that contain high levels of heavy metals, which come from industrial and agricultural wastes or human activities. Marine organisms accumulate these metals from water, food, sediment and some suspended particulate materials (Kalay and Canli, 2000). It has also been observed that fish species accumulate heavy metals to concentrations many times higher than that present in the water or sediments in which they dwell (Khoshnood and Khoshnood, 2013). Therefore, they have been used for marine pollution monitoring (Agusa et al., 2005; Bat et al., 2012).

Humans who consume fish regularly may be exposed to relatively higher levels of heavy metals by eating fish contaminated with heavy metals. Edible fish are often contaminated with heavy metals as a result of agricultural technology, industrial pollution, sewage drainage and other sources, which could affect human health and cause chronic diseases when these metals exceed the tolerable limits (Zyadah and Abdel-Baky, 2000).

This study, therefore, assessed the levels of five heavy metals, zinc ( $\mathrm{Zn})$, lead $(\mathrm{Pb})$, copper (Cu), iron (Fe), and manganese ( $\mathrm{Mn})$ in the sediment and muscles of eight fish species (Alestes sp., Mormyrus sp., Tilapia zillii, Tilapia “wesafu” Gymnarchus niloticus, Sphyreana sp. Polydactilus quadrifilis and Chrysichthys nigrodigitatus) from Epe Lagoon, Nigeria. The study also assessed whether the consumption of these fish species from Epe Lagoon could exceed the established total weekly intake of metals.

Epe Lagoon (Fig. 1) lies between $03^{\circ} 50^{\prime}-04^{\circ} 10^{\prime} \mathrm{N}$ and $05^{\circ} 30^{\prime}-05^{\circ} 40^{\prime} \mathrm{E}$. It has a surface of over $243 \mathrm{~km}^{2}$ and is located between two other lagoons, the Lekki Lagoon (freshwater) in the east and Lagos Lagoon (brackish water) in the west. The lagoon is connected to the sea through the Lagos Harbour (Uwadie, 2010). This lagoon has a six m maximum depth; still, some sectors of the lagoon are comparatively shallow with a minimum depth of one $\mathrm{m}$. The vegetation surrounding the lagoon is of the mangrove swamp type (Fashina-Bombata and Megbowon, 2012).

\section{MATERIAL AND METHODS}

Fish samples were collected from catches of local fishermen in Ijede, Ikose, and Ejrin all in Epe Lagoon area. boxes.

All the fish samples were transported immediately to the laboratory in ice

All the sediments samples were collected from the three stations using core sampler and transferred into polyethylene bags and later transported to the laboratory in ice boxes. 


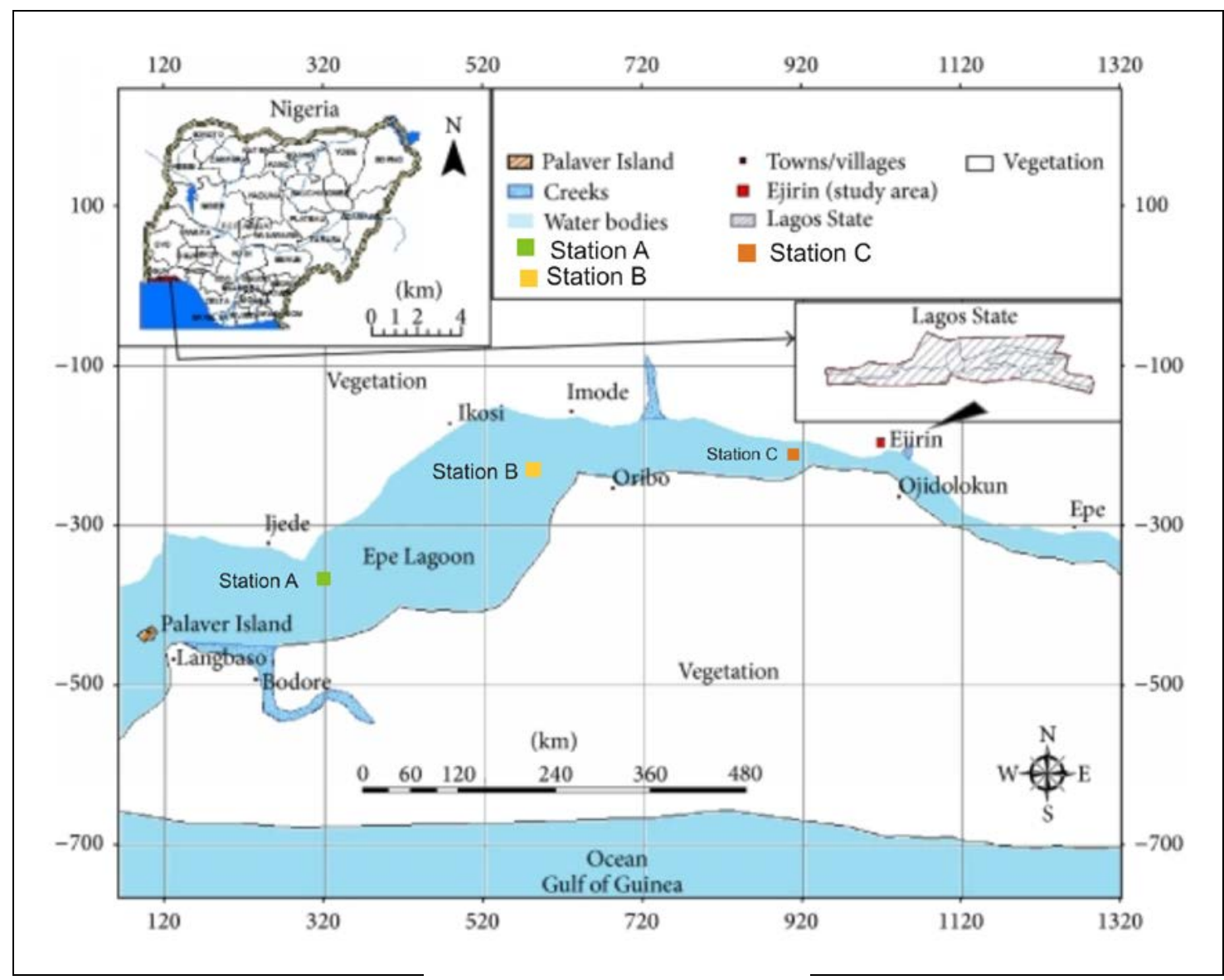

Figure 1: Map of Epe Lagoon.

The fish muscles analysed were collected in triplicates from different parts of the fish body. The fish samples were oven dried at $105^{\circ} \mathrm{C}$ for about 12 hours. All glassware used was washed and rinsed with distilled water several times, then washed in $10 \% \mathrm{HCl}$ before use to avoid contamination.

The fish samples were digested using the wet digestion procedure according to Asegbeloyin et al. (2010). Muscle tissues were taken from various parts of each fish and homogenized. Four $\mathrm{g}$ of the homogenized muscles (without skin) were taken from each specimen and placed in $300 \mathrm{ml}$ Kjldahl digestion tubes. $10 \mathrm{~g}$ of each dried sample was digested in $60 \mathrm{ml}$ of freshly prepared $1: 1 \mathrm{HNO}_{3} / \mathrm{H}_{2} \mathrm{O}_{2}$ solution at $160^{\circ} \mathrm{C}$ on a hot plate for about one hour until the contents were reduced to five $\mathrm{ml}$ each. The residue was then filtered separately with Whatman filter paper (number 42) and the filtrates transferred to a standard flask and distilled, de-ionized water was added to achieve $25 \mathrm{ml}$. The Atomic absorption spectrometer (AAS) (Analyst 200, Perkin Elmer) was then used to determine the concentrations of $\mathrm{Pb}, \mathrm{Mn}$, $\mathrm{Cu}, \mathrm{Fe}$, and $\mathrm{Zn}$ in the fish samples. 
Laboratory blanks were prepared to ensure that the samples and chemicals used were not contaminated. They were analysed by atomic absorption spectrophotometry before the samples, and their values were subtracted to ensure that the equipment read only the exact values of heavy metals. Each set of digestion had its own acid blank and was corrected by using its blank. The sediments were dried at $105^{\circ} \mathrm{C}$, grinding, sieving and about (1.0 gm) of the most fine dried grains were digested with a mixture of concentrated $\mathrm{H}_{2} \mathrm{O}_{2}, \mathrm{HCl}$, and $\mathrm{HNO}_{3}$ as the method described in Page et al. (1982) and preserved in a refrigerator until analysis.

SPSS statistical software was used to obtain indices like mean, standard deviation, and parameters correlation. The mean differences were divided at $\mathrm{P}<0.05$ levels of significance.

\section{RESULTS}

\section{Heavy metal concentration in sediments and fish species}

The mean heavy metals concentrations in the sediments and fish species are presented in table 1. Heavy metals concentration in sediment samples were in the range of $1.26 \pm 0.01$ recorded for $\mathrm{Mn}$ to $10.73 \pm 0.04$ recorded for $\mathrm{Zn}$. These values were all below the permissible limits in soils. The results of heavy metals in the fish samples reveal that $\mathrm{Zn}$ recorded the highest values in all the fish species followed by $\mathrm{Fe}, \mathrm{Pb}, \mathrm{Cu}$ and $\mathrm{Mn}$ (Tab. 1).

There were slight differences among the heavy metal concentrations of the eight fish species sampled. The herbivore, Polydactylus quadrifilis, (Shiny nose) had the lowest concentration of metal in its muscle. None of the fish species sampled had a consistently high level for all the five metals analysed. Gymnarchus niloticus had the highest levels of zinc; Tilapia "wesafu" had the highest levels of lead and copper; Mormyrus sp. had the highest levels of iron and Chrysichthys nigrodigitatus had the highest levels of manganese. The overall average concentrations of $\mathrm{Zn}, \mathrm{Pb}, \mathrm{Cu}, \mathrm{Fe}$, and $\mathrm{Mn}$ in the muscles of the eight fish species were 11.32; 4.80; 2.76; 7.46 and 1.13 respectively. This gave a ranking of: $\mathrm{Zn}>\mathrm{Fe}>\mathrm{Pb}>\mathrm{Cu}>\mathrm{Mn}$. The metal levels in the muscles of each fish species gave a similar ranking.

G. niloticus had a significantly higher $(\mathrm{P}<0.05)$ mean concentration of Zn $(15.78 \pm$ 0.04 ) than all other species, followed by T. "wesafu" with an average concentration of $13.13 \pm$ 1.10. The average concentration of $\mathrm{Zn}$ in the fish muscles was in the order Mormyrus sp. $>C$. nigrodigitatus $>$ Sphyreana sp. $>$ Alestes sp. $>$ T. zilli $>$ P. quadrifilis with values of $12.39 \pm$ $1.58,11.35 \pm 0.05,10.81 \pm 0.03,9.79 \pm 0.05$ respectively (Fig. 2).

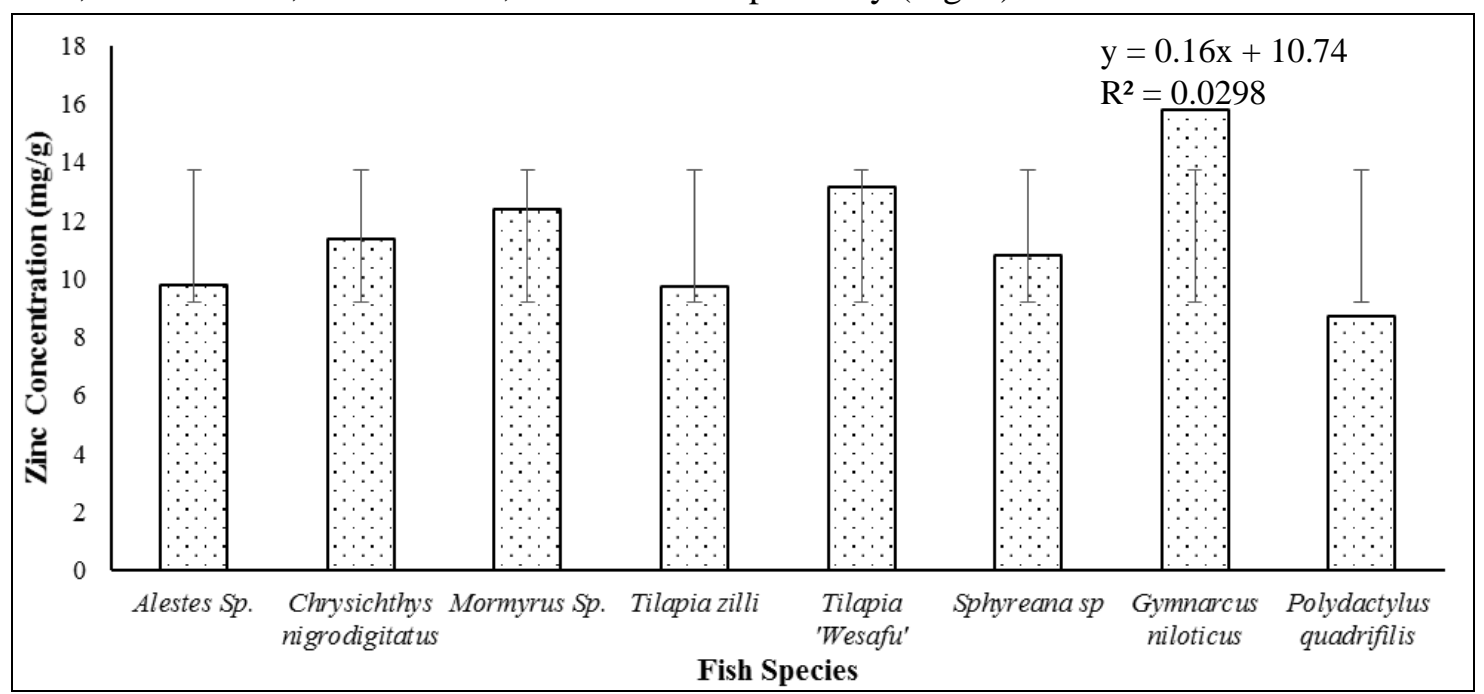

Figure 2: Concentration of $\mathrm{Zn}$ in the muscles of fish species. 
Lead was detected in all eight fish species and higher than the WHO/FAO maximum limit of two $\mathrm{mg} / \mathrm{g}$. The concentration of $\mathrm{Pb}$ was significantly $(\mathrm{P}<0.05)$ higher in $\mathrm{T}$. "wesafu" with an average value of $5.88 \pm 0.10$ than the other fish species. The average concentration of $\mathrm{Pb}$ was in the following order Mormyrus sp. $>$ G. niloticus $>$ C. nigrodigitatus $>$ Sphyreana sp. $>$ Alestes sp. $>$ T. zilli $>$ P. quadrifilis with values of $5.83 \pm 0.17,5.69 \pm 0.014 .62 \pm 0.02$, $4.11 \pm 0.12,3.84 \pm 0.21$ respectively (Fig. 3).

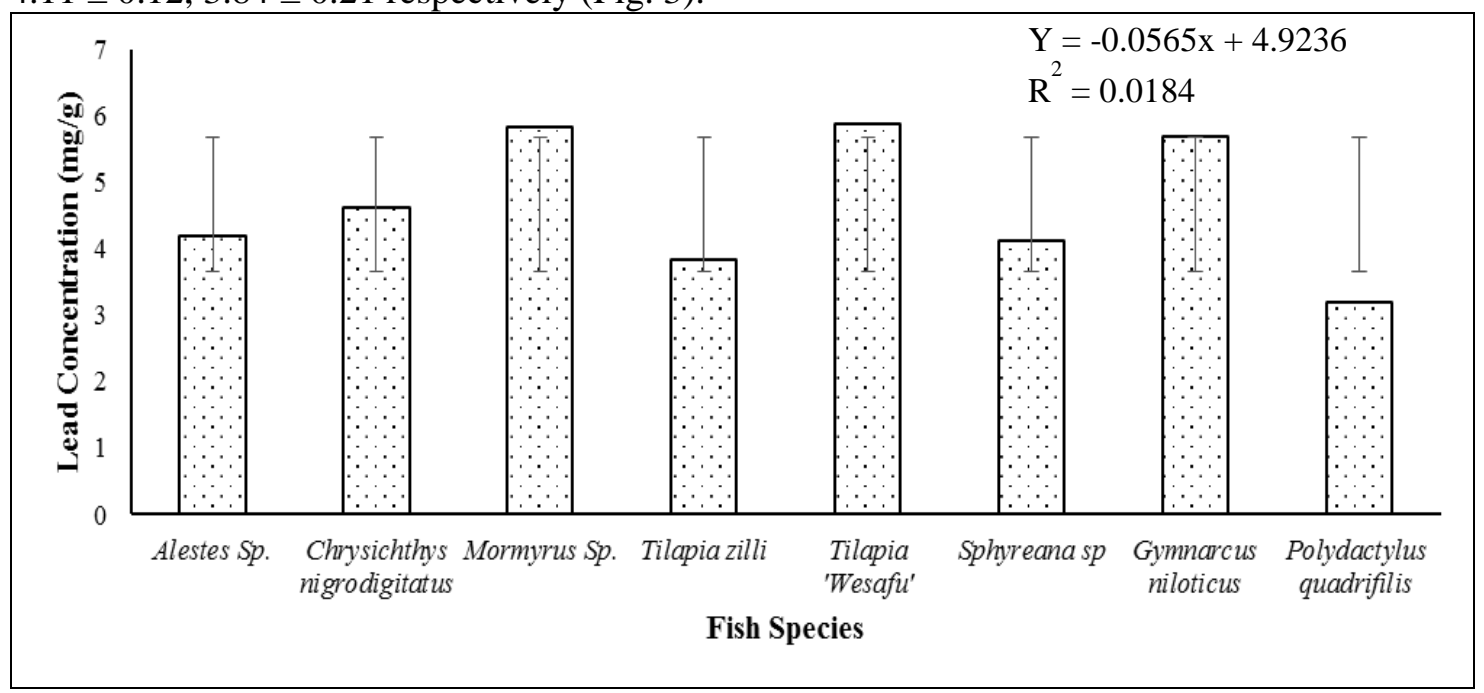

Figure 3: Concentration of lead in the muscles of fish species.

$\mathrm{Cu}$ concentration was significantly $(\mathrm{P}<0.05)$ higher in $\mathrm{T}$. "wesafu" than the other fish species with an average value of $3.31 \pm 0.07$ followed by G. niloticus with an average value of $2.97 \pm 0.00$. The average concentration of $\mathrm{Cu}$ in the muscles of the remaining fish species was Mormyrus sp. $=$ C. nigrodigitatus $>$ Sphyreana sp. $>$ Alestes sp. $>$ T. zillii $>P$. quadrifilis with values of $2.94 \pm 0.34,2.82 \pm 0.00,2.57 \pm 0.14,2.08 \pm 0.03$ and $2.04 \pm 1.07$ respectively (Fig. 4).

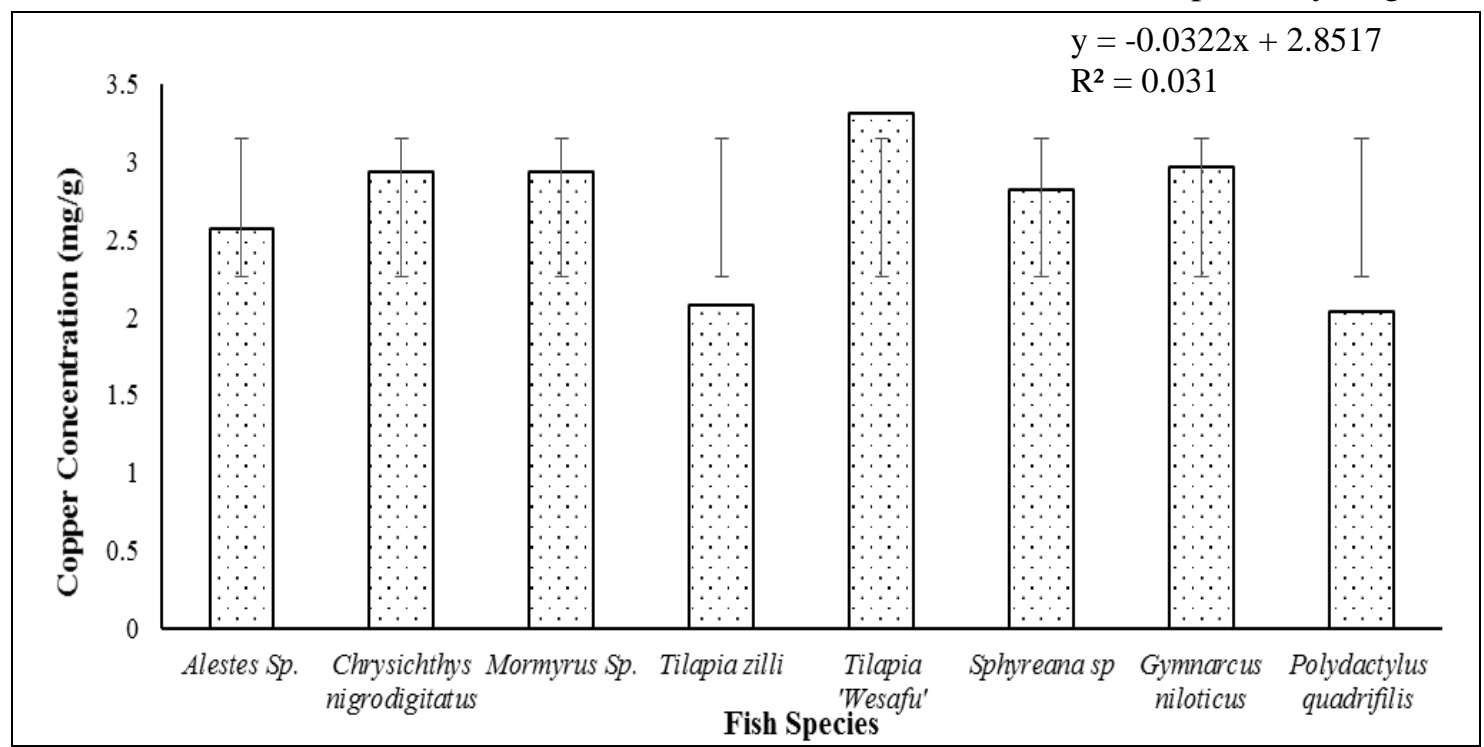

Figure 4: Concentration of copper in the muscles of fish species. 
The average concentration of Fe was in the following order: Mormyrus sp. $>G$. niloticus $>$ C. nigrodigitatus $>$ T. "wesafu" $>$ Sphyreana sp. $>$ T. zilli $>$ Alestes sp. $>P$. quadrifilis, with average values of $8.69 \pm 0.09,8.11 \pm 0.01,8.02 \pm 0.02,7.75 \pm 0.37,7.28 \pm$ $0.08,7.27 \pm 0.16,6.80 \pm 0.03$ and $4.37 \pm 2.48$ respectively. The average concentration of $\mathrm{Fe}$ in Mormyrus sp. was significantly ( $\mathrm{P}<0.05$ ) higher than in the other fish species sampled (Fig. 5).

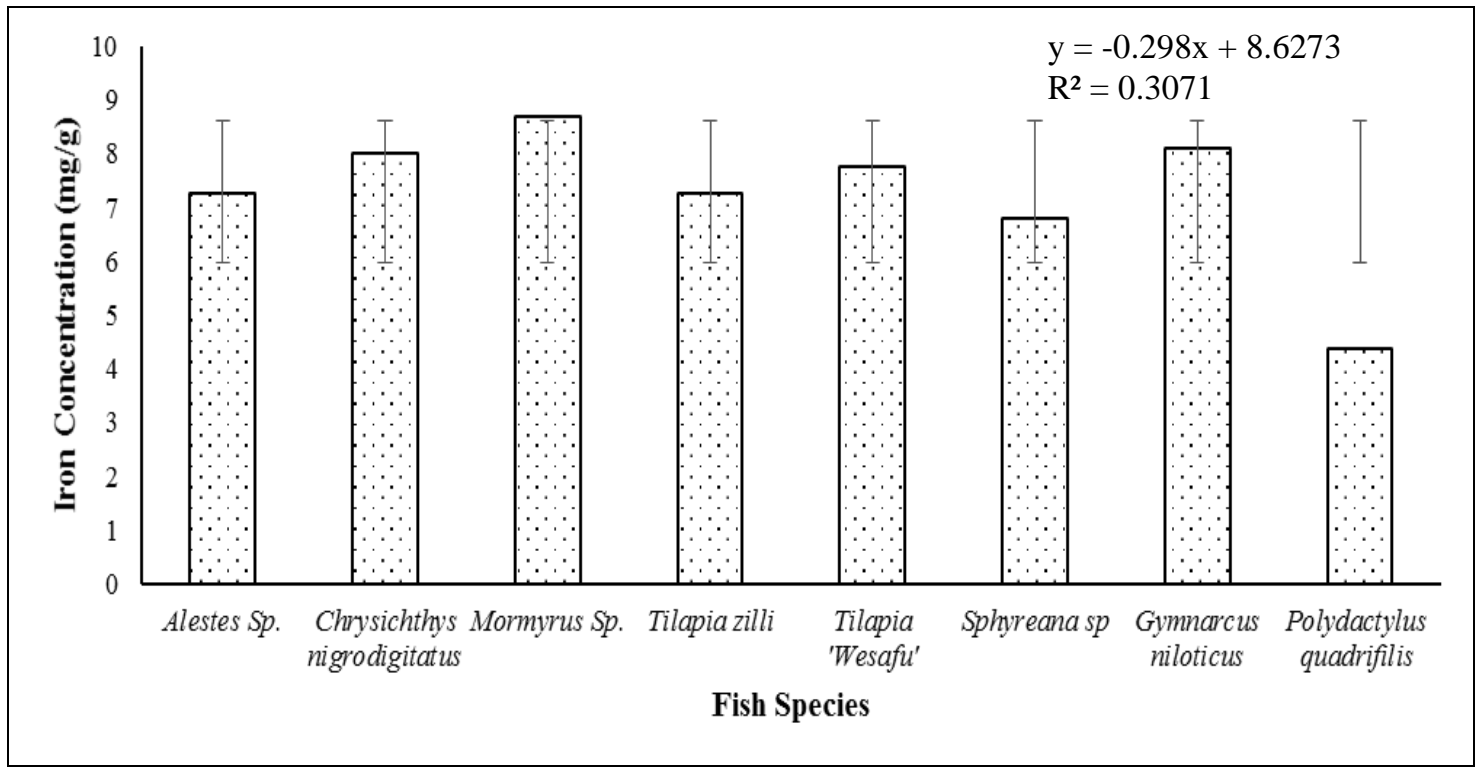

Figure 5: Concentration of iron in the muscles of fish species.

Average concentration of $\mathrm{Mn}$ was in the following order: C. nigrodigitatus $>\mathrm{T}$. "wesafu" > Mormyrus sp. $>$ G. niloticus $>$ Sphyreana sp. $>$ Alestes sp. $>$ T. zillii $>P$. quadrifilis with the following values: $1.24 \pm 0.24,1.23 \pm 0.03,1.17 \pm 0.08,1.15 \pm 0.00,1.11 \pm$ $0.00,1.05 \pm 0.04,1.02 \pm 0.05$ and $0.87 \pm 0.25$ respectively. There were significant $(\mathrm{P}<0.05)$ differences in Mn concentrations among fish species (Fig. 6).

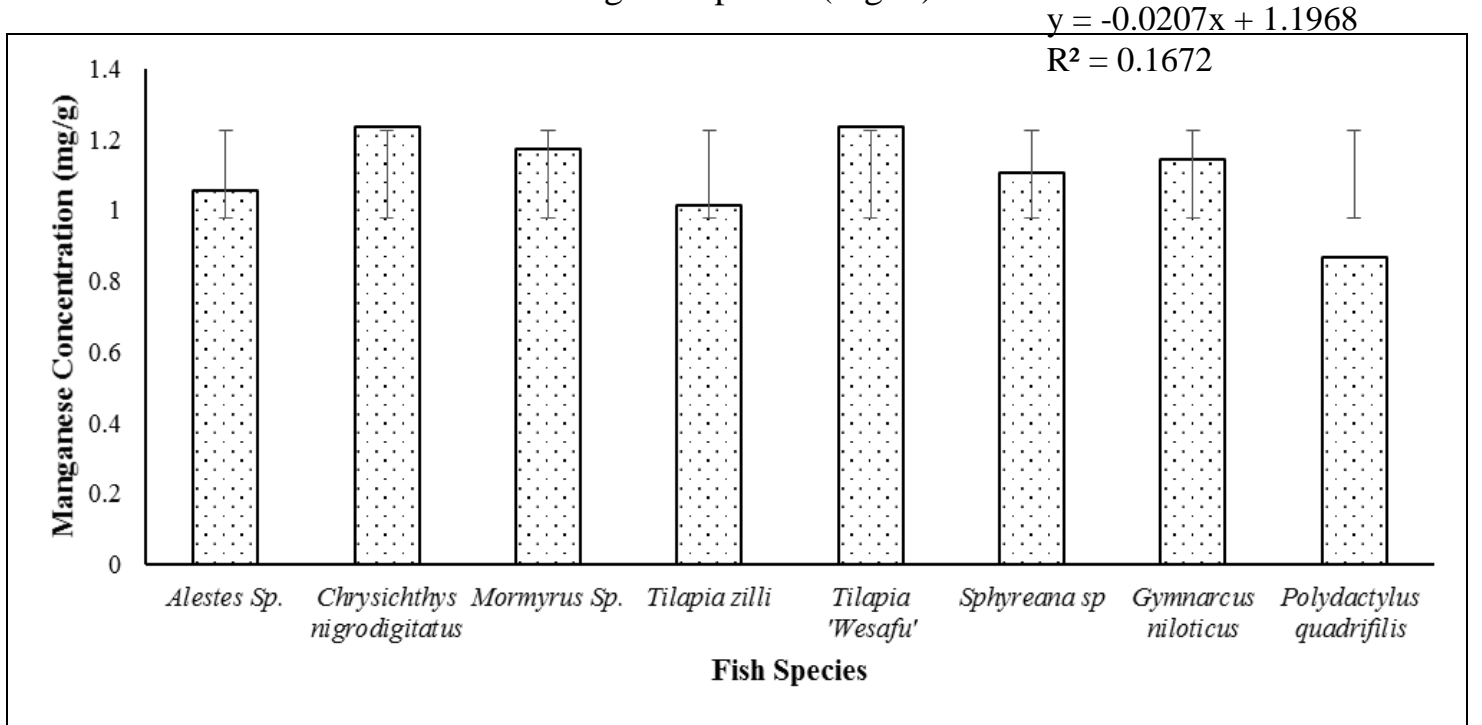

Figure 6: Concentration of manganese in the muscles of fish species. 


\section{Health-risk assessment for fish consumption}

Table 2 shows the estimated average daily consumption and total health quotient (THQ) of heavy metals per person based on an average weight of $70 \mathrm{~kg}$. The estimated daily intake of $\mathrm{Zn}, \mathrm{Pb}, \mathrm{Cu}, \mathrm{Fe}$, and $\mathrm{Mn}$ in all fish species in this study ranged from 0.0-0.023, 0.0011.955, 0.0-0.052, 0.0-0.436, and 0.0-0.003 lg/day/person, respectively. The average daily intake of metals through fish consumption was as follows: $\mathrm{Zn}>\mathrm{Mn}>\mathrm{Cu}>\mathrm{Fe}>\mathrm{Pb}$.

\section{DISCUSSION}

\section{Heavy metal concentration in fish species}

Bahnasawy et al. (2009a) observed that fish muscle is not an active tissue in accumulating heavy metals, but it is the most edible part of the fish that is consumed. It has also been documented that some fish in polluted water bodies may accumulate substantial amounts of metals in their muscles, and this could exceed the maximum acceptable limits (Kalay and Canli, 2000). An appreciable amount of scientific references is accessible on heavy metal concentrations in fish but not much in the various fish species from Epe Lagoon. This research dealt with eight different fish species from this lagoon. This study revealed that the eight different fish species had different mean concentrations of heavy metals in their muscles as shown in table 1 . Heavy metal bioaccumulation in fish is species-dependent. Feeding habits and habitats where the species dwell are also linked to heavy metal accumulation in fish muscles (Al-Majed and Preston, 2000; Yilmaz, 2009). The variations of heavy metal concentrations in the different fish species could also be attributed to size (body weight and length), gender, age and growth rates, types of tissues analysed, and physiological conditions (Canli and Atli, 2003; Raja et al., 2009). The variation in the water body due to the type and level of water pollution, chemical form of metal in the water, water temperature, $\mathrm{pH}$ value, concentrations, oxygen concentration, and water transparency are also factors that influence heavy metal in the different fish species. The geographical location and season of catch could also give different metal concentrations even in the same fish species (Dural et al., 2007; Bahnasawy et al., 2009b).

The eight fish species contained $\mathrm{Pb}, \mathrm{Fe}$, and $\mathrm{Mn}$ above the acceptable limits recommended for human consumption as shown in table 1 . $\mathrm{Zn}$ concentrations ranged from $8.73 \mathrm{mg} / \mathrm{g}$ to $15.78 \mathrm{mg} / \mathrm{g}$ among the fish species with a mean concentration of $12.26 \mathrm{mg} / \mathrm{g}$. This concentration is much higher than that recorded by Hossam et al. (2012) from Gaza fishing harbour in the Mediterranean Sea along the Gaza coast, Palestine, in which the concentrations of zinc ranged from $13.56 \mu \mathrm{g} / \mathrm{g}$ to $40.43 \mu \mathrm{g} / \mathrm{g}$ with mean concentration of 26.9 $\mu \mathrm{g} / \mathrm{g}(0.0269 \mathrm{mg} / \mathrm{g})$. These levels of Zn concentration are much higher than the tolerable weekly intake (PTWI) of seven $\mathrm{mg} / \mathrm{kg}$ body weight equivalent to $490 \mathrm{mg} /$ week for a $70 \mathrm{~kg}$ adult (FAO/WHO, 2004). G. niloticus had the highest mean concentrations of heavy metals, potentially because it is at the peak of the food chain and a heavy carnivore. Taiwo et al. (2016) observed a similar seasonal trend in the same water body with regards to heavy metals in the muscle of G. niloticus, though in their study, T. "wesafu" had the highest metal content. There is no documented literature on the heavy metal content of G. niloticus in other water bodies in Nigeria. This fish species is indigenous to Africa and the only species in its family Gymnarchidae. The relatively undocumented T. "wesafu" had the second highest concentrations of $\mathrm{Zn}$ and $\mathrm{Pb}$ followed by Mormyrus sp. In a previous study, Taiwo et al. (2012) observed that T. "wesafu" raised in a rizi-pisciculture system were low in heavy metal content. However, a similar study conducted by Taiwo et al. (2016) on seasonal variation of 
heavy metals in Epe Lagoon showed that Tilapia "wesafu" had the highest concentration of heavy metals, indicating that this water body is relatively polluted (Hamza-Chaffai et al., 1996), at least in the area where they were caught. Elnabris et al. (2013) noted that due to interspecific differences, when assessing the levels of heavy metals in fish, it should be compared to results of the same species caught within the same water body.

The high levels of heavy metals in Mormyrus sp. are similar to the findings of Nwani et al. (2009) in Anambra River. This high metal content could also be influenced by its feeding habits, as it feeds on detritus, diatoms, algae, and microscopic invertebrates. It has been observed that animals which feed on such usually have high metal concentrations in their muscles (Kilgour, 1991).

The provisional tolerable weekly intake (PTWI) for lead is $0.3 \mathrm{mg} / \mathrm{kg}$ body weight (FAO/WHO, 2004). This result revealed that fish in Epe Lagoon contained lead above the FAO/WHO safe standard level for consumption. This is contrary to Stancheva et al. (2013) on heavy metal and proximate composition of Black Sea sprat and Goby where the concentration of lead is $0.08 \mathrm{mg} / \mathrm{kg} \mathrm{w}$. w. (wet weight) and $0.03 \mathrm{mg} / \mathrm{kg} \mathrm{w}$. w. respectively, which is lower than the concentration of $\mathrm{Pb}$ found in fishes from Epe Lagoon.

The proposed acceptable limits of $\mathrm{Cu}$ concentrations in fish species as recorded by FAO/WHO (1989), EU (2001) and Turkish guidelines (TFC, 2002) is about $30 \mu \mathrm{g} / \mathrm{g} \mathrm{(0.03}$ $\mathrm{mg} / \mathrm{g}$ ). It is prevailing the fact that, the concentrations of $\mathrm{Cu}$ found in tissues of all the fish species in the present study are over the recommended value. This finding agrees with previous observations recorded by Adedeji and Okocha (2011) on bioconcentration of heavy metals in prawns and water from Epe Lagoon and Asejire River in Southwest Nigeria that Epe Lagoon contains copper above the acceptable limit.

Mormyrus sp. had the highest concentration of iron $(8.69 \mathrm{mg} / \mathrm{g})$ while Polydactylus quadrafilis had the lowest concentration $(4.37 \mathrm{mg} / \mathrm{g})$. However, the maximum limit recommended by the IAEA (2003) is $146 \mathrm{mg} / \mathrm{kg}$ indicating that the concentrations of iron in the muscle of the fish species were far above the acceptable limits. The high levels of Fe in the muscle of the fishes analysed concur with the previous findings on assessment of heavy metals in muscles and bones of fish and shellfish from Epe Lagoon by Taiwo et al. (2016) where the concentration of Fe was over the maximum recommended level of WHO.

The concentrations of $\mathrm{Mn}$ ranged from $1.24 \mathrm{mg} / \mathrm{g}$ to $0.87 \mathrm{mg} / \mathrm{g}$ in the fish from Epe Lagoon. The permissible limit of manganese concentrations in fish by the Turkish Food Codes (TFC) is about $20 \mu \mathrm{g} / \mathrm{g}$ (TFC, 2002; Dural et al., 2007; Yilmaz, 2009; Türkmen et al., 2009). The concentration of Mn found in the tissues of the fish species was least in Polydactylus quadrafilis, which was higher than the acceptable TFC limit. The results of this study differ from that obtained by Taiwo et al. (2016) on the concentration of Mn from the same lagoon. However, Taoheed and Said (2014) observed very low levels of manganese in Alestes sp. and $T$. zillii, which were below the tolerable acceptable limits of metal consumption in river Challawa in Kano State, Nigeria. The metal concentrations levels of $\mathrm{Fe}, \mathrm{Pb}, \mathrm{Cu}$, and $\mathrm{Zn}$ in Alestes sp. and C. nigrodigitatus from Afikpo, Ebonyi State, Nigeria were comparable to this study, which were above the maximum permissible limit (Oti-Wilberforce et al., 2016).

Demirezen and Uruc (2006) observed that $\mathrm{Cu}, \mathrm{Mn}, \mathrm{Fe}$, and $\mathrm{Zn}$ are essential elements required by a wide variety of enzymes, other cell components, and vital functioning in all living organisms, but very high intakes can cause health problems. Lead has no biological role and is toxic to humans and other living organisms at very low concentrations. In this study, the overall average concentrations of metals were in the order of $\mathrm{Zn}>\mathrm{Fe}>\mathrm{Pb}>\mathrm{Cu}>\mathrm{Mn}$. This was at variance with the study of Elnabris et al. (2013) where the concentrations of essential elements were higher than the non-essential elements. 


\section{Heavy metal concentrations vs. international dietary standards and guidelines}

There are Nigerian food safety standards, but none are currently available regarding heavy metal concentration in fish. Therefore, the results obtained in this study for muscle samples of fish were compared with limit values and guidelines found in the literature. The levels of $\mathrm{Zn}$ and $\mathrm{Cu}$ were lower than the maximum levels and guidelines values described in the literature. The levels of $\mathrm{Pb}, \mathrm{Fe}$, and $\mathrm{Mn}$ tested in the muscles of the eight fish species were higher than the limit values for fish proposed by the European Community (EU, 2001). As a result of such high levels, it can be ascertained that the fish species in Epe are not entirely fit for human consumption.

Table 1: Heavy metal concentration in fish species from Epe Lagoon.

\begin{tabular}{|l|c|c|c|c|c|}
\hline \multicolumn{1}{|c|}{ Fish species } & Zn & $\mathrm{Pb}$ & $\mathrm{Cu}$ & $\mathrm{Fe}$ & $\mathrm{Mn}$ \\
\hline Sediment & $10.73 \pm 0.04^{\mathrm{bc}}$ & $5.76 \pm 0.03^{\mathrm{a}}$ & $3.32 \pm 0.02^{\mathrm{a}}$ & $6.84 \pm 0.06^{\mathrm{b}}$ & $1.26 \pm 0.01^{\mathrm{a}}$ \\
\hline $\begin{array}{l}\text { Alestes } \\
\text { sp. }\end{array}$ & $9.79 \pm 0.05^{\mathrm{bc}}$ & $4.19 \pm 0.29^{\mathrm{bc}}$ & $2.57 \pm 0.14^{\mathrm{ab}}$ & $7.27 \pm 0.16^{\mathrm{ab}}$ & $1.05 \pm 0.04^{\mathrm{ab}}$ \\
\hline $\begin{array}{l}\text { Chrysichthys } \\
\text { nigrodigitatus }\end{array}$ & $11.35 \pm 0.05^{\mathrm{bc}}$ & $4.62 \pm 0.02^{\mathrm{ab}}$ & $2.94 \pm 0.01^{\mathrm{a}}$ & $8.02 \pm 0.02^{\mathrm{ab}}$ & $1.24 \pm 0.24^{\mathrm{a}}$ \\
\hline $\begin{array}{l}\text { Mormyrus } \\
\text { sp. }\end{array}$ & $12.39 \pm 1.58^{\mathrm{abc}}$ & $5.83 \pm 0.17^{\mathrm{a}}$ & $2.94 \pm 0.34^{\mathrm{a}}$ & $8.69 \pm 0.09^{\mathrm{a}}$ & $1.17 \pm 0.08^{\mathrm{ab}}$ \\
\hline $\begin{array}{l}\text { Tilapia } \\
\text { zillii }\end{array}$ & $9.71 \pm 0.35^{\mathrm{bc}}$ & $3.84 \pm 0.21^{\mathrm{c}}$ & $2.08 \pm 0.03^{\mathrm{b}}$ & $7.28 \pm 0.08^{\mathrm{ab}}$ & $1.02 \pm 0.05^{\mathrm{ab}}$ \\
\hline $\begin{array}{l}\text { Tilapia } \\
\text { "wesafu” }\end{array}$ & $13.13 \pm 1.10^{\mathrm{ab}}$ & $5.88 \pm 0.10^{\mathrm{a}}$ & $3.31 \pm 0.07^{\mathrm{a}}$ & $7.75 \pm 0.37^{\mathrm{ab}}$ & $1.23 \pm 0.03^{\mathrm{a}}$ \\
\hline $\begin{array}{l}\text { Sphyreana } \\
\text { sp. }\end{array}$ & $10.81 \pm 0.03^{\mathrm{bc}}$ & $4.11 \pm 0.12^{\mathrm{bc}}$ & $2.82 \pm 0.06^{\mathrm{ab}}$ & $6.80 \pm 0.03^{\mathrm{b}}$ & $1.11 \pm 0.12^{\mathrm{ab}}$ \\
\hline $\begin{array}{l}\text { Gymnarcus } \\
\text { niloticus }\end{array}$ & $15.78 \pm 0.04^{\mathrm{a}}$ & $5.69 \pm 0.01^{\mathrm{a}}$ & $2.97 \pm 0.06^{\mathrm{a}}$ & $8.11 \pm 0.01^{\mathrm{ab}}$ & $1.15 \pm 0.03^{\mathrm{ab}}$ \\
\hline $\begin{array}{l}\text { Polydactylus } \\
\text { quadrifilis }\end{array}$ & $8.73 \pm 4.04^{\mathrm{c}}$ & $3.19 \pm 1.94^{\mathrm{c}}$ & $2.04 \pm 1.07^{\mathrm{b}}$ & $4.37 \pm 2.48^{\mathrm{c}}$ & $0.87 \pm 0.25^{\mathrm{b}}$ \\
\hline
\end{tabular}

* Means with different superscript along same column are significantly different $(\mathrm{P}<0.05)$,

$* \pm$ value is the standard deviation.

Table 2: Comparison of heavy metals concentration in fish and Total Health Quotient.

\begin{tabular}{|c|c|c|c|c|}
\hline Metal & $\begin{array}{c}\text { Concentration } \\
(\mathrm{mg} / \mathrm{kg})\end{array}$ & $\begin{array}{c}\text { EDI } \\
(\mathrm{mg} / \mathrm{kg} / \text { person) }\end{array}$ & $\begin{array}{c}\text { RDDA } \\
(\mathrm{mg} / \text { day/person) }\end{array}$ & THQ \\
\hline $\mathrm{Zn}$ & 12.225 & $0.0-0.023$ & 70 & 0.019 \\
\hline $\mathrm{Pb}$ & 5.755 & $0.001-1.955$ & 0.25 & 1.715 \\
\hline $\mathrm{Cu}$ & 3.726 & $0.0-0.052$ & 0.35 & 0.044 \\
\hline $\mathrm{Fe}$ & 7.616 & $0.0-0.436$ & 56 & 0.404 \\
\hline $\mathrm{Mn}$ & 1.436 & $0.0-0.003$ & 9.8 & 0.002 \\
\hline
\end{tabular}

EDI - Estimated daily consumption RDDA - Recommended daily dietary allowance THQ - Total health quotient. 


\section{CONCLUSIONS}

This study has provided information on the heavy metal concentrations on sediment and eight fish species from Epe Lagoon. The study indicated variations on the levels of heavy metals investigated $(\mathrm{Zn}, \mathrm{Fe}, \mathrm{Pb}, \mathrm{Cu}$, and $\mathrm{Mn})$. $\mathrm{Zn}$ recorded the highest values in all the fish species followed by $\mathrm{Fe}, \mathrm{Pb}, \mathrm{Cu}$, and $\mathrm{Mn}$. G. niloticus had highest level of heavy metals concentration and $P$. quadrafilis had the lowest.

The concentration of the heavy metals tested in the muscles of the fish species from Epe Lagoon, Lagos State were above the recommended maximum acceptable limits in fish food consumption. Therefore, these fishes should not be eaten regularly or in large quantities, as it could be a source of health concern. It is essential that the PTWI of these metals is not exceeded. To assess public health risk of the Epe Lagoon fish consumption, comparison of metal levels in muscles of the current study with the maximum permissible limits (MPL) for human consumption established by different organizations was made. 


\section{ACKNOWLEDGEMENTS}

We would like to send our appreciation to members of University of Putra, Faculty of Environmental Studies, Aquatic Laboratory, UPM Putra for helping the team. This study was sponsored by UPM Putra Grant GPM/2013/9422500 (University Putra Malaysia). 


\section{REFERENCES}

1. Adedeji O. B. and Okocha R. C., 2011 - Bio-concentration of heavy metals in prawns and water from Epe Lagoon and Asejire River in Southwest Nigeria, Journal of Applied Science, Environment and Sanitation, 6, 3, 377-384.

2. Agusa T., Kunito T., Yasunaga G., Iwata H., Subramanian A., Ismail A. and Tanabe S., 2005 Concentrations of trace elements in marine fish and its risk assessment in Malaysia, Marine Pollution Bulletin, 51, 8-12, 896-911.

3. Akköz C., 2016 - The determination of some pollution parameters, water quality and heavy metal concentrations of Aci Lake (Karapinar/Konya, Turkey), Transylvanian Review of Systematical and Ecological Research, 18.3, The Wetlands Diversity, 1-20.

4. Al-Majed N. B. and Preston M. R., 2000 - An assessment of the total and methyl mercury content of zooplankton and fish tissue collected from Kuwait territorial waters, Marine Pollution Bulletin, 40, 298-307.

5. Asegbeloyin J. N., Onyimonyi A. E., Ujam O. T., Ukwueze N. N. and Ukoha P. O., 2010 Assessment of toxic trace metals in selected fish species and parts of domestic animals, Pakistan Journal of Nutrition, 9, 3, 213-215.

6. Astratinei V. and Varduca I., 2008 - Effect of metal pollution on aquatic microorganisms: a case study in mining areas (Romania), Transylvanian Review of Systematical and Ecological Research, 6, The Wetlands Diversity, 109-116.

7. Aziz T. N. A. and Hashim N. R., 2011 - Heavy metal concentrations in an important mangrove palm (Nypa fruticans), in Rembau-Linggi Mangrove Forest (Peninsular Malaysia), Transylvanian Review of Systematical and Ecological Research, 12, The Wetlands Diversity, 111-116.

8. Bahnasawy M. H., Khidr A. A. and Dheina N. A., 2009a - Assessment of heavy metals concentrations in water, plankton and fish of lake Manzala, Egypt, Egyptian Journal of Aquatic Biology and Fisheries, 13, 117-133.

9. Bahnasawy M., Khidr A. and Dheina N., 2009b - Seasonal variations of heavy metals concentrations in Mullet, Mugil cephalus and Liza ramada (Mugilidae) from lake Manzala, Egypt, Journal of Applied Science Resources, 5, 845-852.

10. Bat L., Sezgin Ustun M. F. and Sahin F., 2012 - Heavy metal concentrations in ten species of fishes caught in sinop coastal waters of the Black Sea, Turkey, Turkish Journal of Fisheries and Aquatic Sciences, 12, 371-376.

11. Boyd C. E. and Tucker C. S., 1992 - Water quality and pond soil analysis for aquaculture, Alabama Agricultural Experimental Station, Auburn University, 183.

12. Canli M. and Atli G., 2003 - The relationships between heavy metal (Cd, Cr, Cu, Fe, Pb, Zn) levels and the size of six Mediterranean fish species, Turkish Journal of Fisheries and Aquatic Sciences, 121, 129-136.

13. Demirezen D. and Uruc K., 2006 - Comparative study of trace elements in certain fish, meat and meat products, Meat Science, 74, 255-260.

14. Dural M., Göksu M. Z. Y. and Özak A. A. 2007 - Investigation of heavy metal levels in economically important fish species captured from the Tuzla Lagoon, Food Chemistry, 102, 1, 415-421, doi: 10.1016/j.foodchem.2006.03.001.

15. Elnabris K. J., Muzyed S. K. and El-Ashgar N. M., 2013 - Heavy metal concentrations in some commercially important fishes and their contribution to heavy metals exposure in Palestinian people of Gaza Strip (Palestine), Journal of the Association of Arab Universities for Basic and Applied Sciences, 13, 1, 44-51.

16. European Union, 2001 - Commission regulation as regards heavy metals directive, 22/EC, number 466.

17. FAO/WHO, 1989 - Evaluation of certain food additives and the contaminants mercury, $\mathrm{Pb}$ and cadmium, WHO Technical Report, series number 505. 
18. FAO/WHO, 2004 - Summary of evaluations performed by the joint FAO/WHO Expert Committee on Food Additives (JECFA, 1956-2003), ILSI Press International Life Sciences Institute.

19. Fashina-Bombata H. and Megbowon I., 2012 - Proximate composition and breeding description of an unidentified cichlid of Epe Lagoon, Southwest, Nigeria commonly called "Wesafu", International Journal of Nutrition and Metabolism, 4, 4, 57-63.

20. Hamza-Chaffai A., Romeo M. and Abed A., 1996 - Heavy metal in difference fish from the Middle Eastern coast of Tunisia, Bulletin Environment Contamination Toxicology, 56, 766-773.

21. Hossam A. Z., Adnan M. A. and Hisham N. W., 2012 - Baseline concentration of heavy metals in fish collected from Gaza fishing harbour in the Mediterranean Sea along Gaza coast, Palestine, Turkish Journal of Fisheries and Aquatic Sciences, www.trjfas.org ISSN 1303-2712, DOI: 10.4194/1303-2712-v17-1-12.

22. Iepure S. and Selescu L., 2009 - Relationship between heavy metals and hyporheic invertebrate community structure in the middle basin of the Arieş River (Transylvania, Romania), Transylvanian Review of Systematical and Ecological Research, 7, The Arieş River Basin, 125-148.

23. International Atomic Energy Agency, 2003 - Analytical Quality Control Services, Vienna, Austria, 407.

24. Kalay M. and Canli M., 2000 - Elimination of essential (Cu, Zn) and non-essential (Cd, Pb) metals from tissue of a fresh water fish Tilapia zilli, Turkish Journal of Zoology, 24, 429-436.

25. Khoshnood Z. and Khoshnood R., 2013 - Health risks evaluation of heavy metals in sea food, Transylvanian Review of Systematical and Ecological Research, 15.1, The Wetlands Diversity, 137-144.

26. Kilgour B., 1991 - Cadmium uptake from cadmium-spiked sediments by four freshwater invertebrates, Bulletin of Environment, Contamination and Toxicology, 47, 70-75.

27. Munoz-Olivas R. and Camara C., 2001 - Speciation related to human health, in Ebdon L., Pitts L., Cornelis R., Crews H., Donad O. F. X. and Quevauviller P. (eds), Trace Element Speciation for Environment, Food and Health, The Royal Society of Chemistry, 331-353.

28. National Special Program for Food Security, 2005 - Farming Nigeria's water. A compilation of newsletter of aquaculture and inland fisheries project, 21, 1-34.

29. Nwani C. D., Nwoye V. C., Afiukwa J. N. and Eyo J. E., 2009 - Assessment of heavy metal concentrations in the tissues (gills and muscles) of six commercially important freshwater fish species of Anambra River south-east Nigeria, Asian Journal of Microbiology, Biotechnology and Environmental Sciences, 11, 1, 7-12.

30. Oti-Wilberforce J. O., Nworie F. and Oti-Wilberforce R. O., 2016 - Comparative assay of heavy metals in gills and muscles of common fishes in Afikpo, Ebonyi State, Nigeria, World Applied Sciences Journal, 34, 2, 268-272.

31. Page A. L., Miller R. H. and Kenney D. R. (eds), 1982 - Heavy metals determination, in Methods of soil analysis, part 2, Chemical and microbiological properties, American Society of Agronomy, Madison, WI, USA, 8.

32. Raja P., Veerasingam S., Suresh G., Marichamy G. and Venkatachalapathy R., 2009 - Heavy metals concentration in four commercially valuable marine edible fish species from Parangipettai Coast, South East Coast of India, International Journal of Animal and Veterinary Advances, 1, 10-14.

33. Stancheva M., Merdzhanova A., Petrova E. and Petrova D., 2013 - Heavy metals and proximate composition of Black Sea sprat (Sprattus sprattus) and goby (Neogobius melanostomus), Bulgarian Journal of Agricultural Science, 19 (Supplement 1), 35-41.

34. Taiwo I. O., Adigbo S. O., Ipinmoroti M. O., Ezeri G. N. O., Bamidele N. A. and Obasa S. O., 2012 - Heavy metal analysis of Tilapia "Wesafu” and hybrid Oreochromis niloticus in RiziPisciculture System, Aquafield, 8, 88-94. 
35. Taiwo I. O., Adeosun F. I., Adeniyi B. T. and Bamidele N. A., 2016 - Assessment of heavy metals in muscles and bones of fish and shell fish from Epe Lagoon, Nigeria, Research, 10, 4, 257-263.

36. Taoheed H. Y. and Said D. M., 2014 - Levels of some heavy metals in six species of fish obtained from Challawa River, Kano, International Journal of Biological and Chemical Sciences, 8, 1, 413-418.

37. TFC, 2002 - Turkish Food Codes, Official Gazette, 23 September, number 24885.

38. Türkmen M., Türkmen A., Tepe Y., Töre Y. and Ateş A., 2009 - Determination of metals in fish species from Aegean and Mediterranean seas, Food Chemistry, 113, 1, 233-237.

39. Uwadie R. E., 2010 - Macroinvertebrates functional feeding groups as indices of biological assessment in a tropical aquatic ecosystem: implications for ecosystem functions, New York Science Journal, 3, 8, 6-15.

40. Yilmaz F., 2009 - The comparison of heavy metal concentrations (Cd, Cu, Mn, Pb and $\mathrm{Zn}$ ) in tissues of three economically important fish (Anguilla anguilla, Mugil cephalus and Oreochromis niloticus) inhabiting Köycegiz Lake-Mulga (Turkey), Turkish Journal of Sciences and Technology, 4, 1, 7-15.

41. Zubcov N., Zubcov E. and Schlenk D., 2008 - The dynamics of metals in fish from Nistru and Prut rivers (Moldova), Transylvanian Review of Systematical and Ecological Research, 6, The Wetlands Diversity, 51-58.

42. Zyadah M. A. and Abdel-Baky T. E., 2000 - Toxicity and bioaccumulation of Cu, Zn and Cd in some aquatic organisms, Bulletin of Environmental Contamination and Toxicology, 64, 5, 740747. 